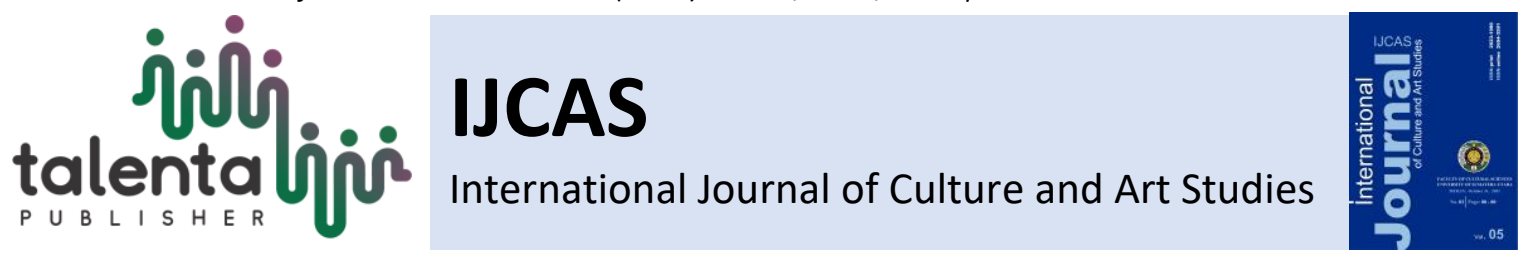

\title{
Carrier Concept in Hindu Religious Scriptures and Sculpture: A Conspectus
}

\author{
T. Panda ${ }^{1 *}$ and R.B. Mohanty ${ }^{2}$ \\ ${ }^{1}$ Department of Botany, Chandbali College, Chandbali-756133, Bhadrak, Odisha, India. \\ ${ }^{2}$ Ex-Reader in Botany, Plot No. 1311/7628, Satya Bihar, Rasulgarh, Bhubaneswar, Odisha, India.
}

\begin{abstract}
The relationship between man and bioresources (plants and animals) based on faith, belief, and tradition concerning gods and goddesses and other such powers are very intense, vast, and multifarious. The paper has a brief account of faith related to carrier or vahana in Hindu religious scriptures and sculpture. A total of 32 animals, ten different categories of birds, and only one plant (flower) are identified, playing the role of carriers of gods and goddesses of the Hindu pantheon. It is discussed that such faith, belief, and practice have a scientific basis and are helpful for the management and preservation of biodiversity.
\end{abstract}

Keywords: Biodiversity, Hindu mythology, Puranas, Vahana, Yoginis

Received 20 August 2021 | Revised 29 September 2021 | Accepted 31 October 2021

\section{Introduction}

Carrier or Vahana is literally "that carries" or that which pulls. It is typically an animal or bird and rarely some mythical entity, which a particular Hindu deity uses as a vehicle (Phyu, 2004; Aye, 2018). Either the deity rides on it for mobility, or at times it is depicted at the side of the deity (Phyu, 2004; Brighenti, 2001). As the Hindus believe in polytheism and practice idol worship, there are a large number as well as category of gods and goddesses described in "Puranas" and other religious scriptures, although limited numbers are carved in wood, metal, or stone into definite figures and worshiped in temples and in other holy places (Khamitkar, 2016; Khin, 2020). Many gods and goddesses are described or observed with a carrier or vahana in sculptures, normally an animal or a bird (Phyu, 2004; Gan, 2004; Agarwala, 1970; Anonymous, 1970; Banarjee, 1980; Sinha, 1950; Wilson, 1961). The type of animal or bird acting as vahana, the purpose of attaching a particular animal to a definite divine being, and the scientific significance of this concept, if any was studied and analyzed from the data gathered from Hindu religious texts and archaeologically important sites during the year 2018-19 to focus on the message behind this depiction and its consequence.

\footnotetext{
*Corresponding author at: Department of Botany, Chandbali College, Chandbali-756133, Bhadrak, Odisha, India. 


\section{$2 \quad$ Materials and Methods}

In order to have a clear basic knowledge regarding the gods and goddesses of Hindu mythology, most of the religious scriptures, including epics and Puranas, were screened, and relevant data were recorded (Agarwala, 1970; Anonymous, 1970; Banarjee, 1980; Sinha, 1950; Wilson, 1961). Moreover, important holy places like temples and archaeological sites of Odisha and India were visited, sculptures of gods and goddesses and their vahanas were observed and studied. Some rare temples like the Saptamatruka temple at Jajpur, 64 yogini temple at Hirapur in Khurda district, and Ranipur- Jharial in Bolangir district of Odisha were also covered for similar purposes.

\section{Results}

From the scrutiny of Hindu religious scriptures, it became evident that there is a description of crores of these super-natural beings or divine entities present in different categories. But there are few prominent ones whose structures are elaborately described in the texts as well as figures were carved into definite structures along with their vahanas placed in temples and worshipped. Often these beings are depicted in a humanoid or partially humanoid form, complete with a set of unique and complex iconography in each case. But their carriers or vahanas are observed to be either a distinct animal or a bird and very rarely a mythical figure. In fact, the total number of 32 animals, ten different categories of birds, and only one plant (flower) are identified, playing the role of carriers of gods and goddesses of the Hindu pantheon (Table 1).

Table 1. Vahanas (carriers) of corresponding Gods /Goddesses

\begin{tabular}{|c|c|c|c|c|c|}
\hline $\begin{array}{l}\text { SI. } \\
\text { No. }\end{array}$ & $\begin{array}{l}\text { Vahana } \\
\text { (Animal) }\end{array}$ & God/Goddess & $\begin{array}{l}\text { Sl. } \\
\text { No. }\end{array}$ & $\begin{array}{l}\text { Vahana } \\
\text { (Animal) }\end{array}$ & God/Goddess \\
\hline 1 & Antelepe & Chandra,Vayu & 24 & Mouse & Ganesh, Yogini \\
\hline 2 & Ass & Yogini & 25 & Musk deer & Yogini \\
\hline 3 & Black buck & Yogini & 26 & Rhino & Dhavdi \\
\hline 4 & Buffalo & Yama,Varahi & 27 & Ram & Agni, Yogini \\
\hline 5 & Bull & Shiva, Parbati & 28 & Scorpion & Yogini \\
\hline 6 & Camel & Ushtra Vahini Devi & 29 & Snake & $\begin{array}{l}\text { Kamakshya, } \\
\text { Manasa, Vishnu }\end{array}$ \\
\hline 7 & Cat & Sasthi Devi & 30 & Tiger & Durga, Parvati \\
\hline 8 & Crab & Yogimi & 31 & Tortoise & $\begin{array}{l}\text { Yamuna, } \\
\text { Varuna }\end{array}$ \\
\hline 9 & Crocodile & Shukra & 32 & Yak & Yogini \\
\hline
\end{tabular}




\begin{tabular}{|c|c|c|c|c|c|}
\hline 10 & Dog & Bhairava,Yogini & $\begin{array}{l}\text { Sl. } \\
\text { No. }\end{array}$ & $\begin{array}{l}\text { Vahana } \\
\text { (Birds) }\end{array}$ & God/Goddess \\
\hline 11 & Donkey & $\begin{array}{l}\text { Kalaratri, Kali, } \\
\text { Shitala }\end{array}$ & 1 & Cockerel & Bahuchara Mata \\
\hline 12 & Elephant & Laxmi, Indra & 2 & Crow & $\begin{array}{l}\text { Shani, } \\
\text { Dhumabati, } \\
\text { Usha }\end{array}$ \\
\hline 13 & Fish & Yogini & 3 & Duck & Yogini \\
\hline 14 & Frog & Yogini & 4 & $\begin{array}{l}\text { Eagle } \\
\text { (Garuda) }\end{array}$ & $\begin{array}{l}\text { Vishnu, } \\
\text { Krushna, } \\
\text { Vaishnavi }\end{array}$ \\
\hline 15 & Goat & Agni, Mangala & 5 & Owl & Lakshmi \\
\hline 16 & Horse & $\begin{array}{l}\text { Ayappan, Buddha, } \\
\text { Chandra,Kalki }\end{array}$ & 6 & Parrot & Kamadev \\
\hline 17 & Jackel & Yogini & 7 & Peacock & $\begin{array}{l}\text { Kartika, } \\
\text { Saraswati }\end{array}$ \\
\hline 18 & Lion & Durga, Rahu & 8 & Pigeon & Rati \\
\hline 19 & Male pig & Yogini & 9 & Swan & $\begin{array}{l}\text { Bramha, } \\
\text { Saraswati }\end{array}$ \\
\hline 20 & Male deer & Yogini & 10 & Vulture & Ketu \\
\hline 21 & Man & Kubera & $\begin{array}{l}\text { Sl. } \\
\text { No. }\end{array}$ & $\begin{array}{l}\text { Vahana } \\
\text { (Plant) }\end{array}$ & God/Goddess \\
\hline 22 & Makara & Ganga, Varuna & 1 & Lotus & $\begin{array}{l}\text { Saraswati, } \\
\text { Laxmi }\end{array}$ \\
\hline 23 & Mangoose & Yogini & & & \\
\hline
\end{tabular}

Mostly the animal carriers are bigger and stronger ones belonging to a mammalian group, signifying as well as reflecting the strength and might of their masters. The only exception is a small mouse carrying the heavy-bodied "Ganapathi" on its back, the god of wisdom, knowledge, and destroyers of all evils. Also, some lower groups of animals like scorpions, crabs, frogs, and fish, etc., are the typical organisms associated with particular "Yoginis," i.e., the female divine but fearsome figures, created and participated with goddess Durga during her war with the demon "Mahisasura." Similarly, most of the bird as vahanas is prominent and common ones signifying the distinct character of their masters. Only one plant or flower, i.e., white and pink colored lotus, is carved as the pedestal of the goddess "Saraswati," the goddess of lesions and knowledge, and goddess Laxmi, the goddess of wealth respectively. 


\section{Discussion and conclusion}

In Hindu religious practices, a large number of gods are worshipped in the form of "Murtis" or indefinite figures and postures (Grieve, 2003; Srivastava and Barmola, 2013). These beings are either aspects of the supreme Brahman, avatars of the supreme being, and significantly powerful entities known as "Devas." The exact nature of belief in regards to each deity, of course, varies between differing Hindu denominations and philosophies. The vehicles of gods and goddesses in Hindu belief and iconography are normally animal or bird mounts that the gods and goddesses ride for their mobility. Of course, there are said to be 33 crores of goddesses and gods as per Hindu mythology (Byrne, 2007, p. 7-11); each one uses a separate vahana or carrier, which symbolically represents the character of its master (Agarwala, 1970; Anonymous, 1970; Banarjee, 1980; Sinha, 1950; Wilson, 1961). For instance, "Nandi," the bull, vahana of lord "Shiva" represent strength and virility; Peacock, the vehicle of the lord "Kartikeya," symbolizes splendor and majesty while swan, the vehicle of lord "Brahma" and goddess "Saraswati," represents wisdom, grace, and beauty. As per another belief, the carrier animal or bird at times symbolizes the evil forces over which the deity dominates. For instance, mounting on peacock, lord Kartikaya rein on its vanity, and being seated on Musika, lord Ganesh crushes the evil forces like a rat. They are at times described as demons or wicked souls which were defeated and transformed into vahanas.

The vehicles of gods and goddesses are not merely the beasts of burden or simple carriers, but they are assigned with some divinity or divine power. They also perform many other tasks along with their principal duty.

(a) The vahanas elevate the status of the deity and serve as status symbols to denote the strength, potency, and rank of the deity in the pantheon.

(b) They are described with incredible mobility, at times act as efficient guards, fought the war with their masters and perform several other obligatory and secondary duties, at times act as divine messengers, teachers with the ability to grant knowledge and liberation as per different religious texts.

(c) They symbolize the elements over which the Gods have control.

(d) They have some abilities to override, control and transform the negative forces or energy, impurities, and attitudes that are present in us or in the creation.

(e) These divine vehicles also symbolize negativity and darkness that prevents us from achieving liberation or experiencing internal peace and happiness.

Cross-culturally, this Hindu mythology is, up to some extent, similar to Greek mythology, i.e., in polytheism, but when later reflects the subjective truth of the Greeks, which is radically different 
from the subjective truth of the Hindus. Moreover, the animal vehicles of Hindu iconography are not consistent with Greek and Roman mythology or belief systems that may tie a particular animal or bird to a particular deity. For instance, when goddess "Laxmi" of the Hindus has an owl, the Goddess "Athena" of ancient Greece is also associated with an owl as her emblem. But the meaning invested by the two different beliefs systems is not the same, nor are the two goddesses themselves similar in character and activities. In Hinduism, since antiquity, the Indian lotus has been a sacred plant. (Beuchert, 2004)

The scientific and practical implication of this carrier concept in Hindu religious belief is that the designated animals and birds are venerated as holy creatures and representatives of their masters, worshipped in some specific rituals and never harmed, fearing divine wrath. It ultimately leads to the protection of those organisms and the overall conservation of biodiversity of the region.

\section{REFERENCES}

[1] Agarwala, V.S. (1970). Ancient Indian folk cults, Indian civilization series, No: V11. Prithivi Prakashan, Varanasi.

[2] Anonymous. (1970). Siva Purana. Ancient Indian tradition and mythology series. Motilal Banarasidass, Delhi.

[3] Aye, K.T. (2018). The vehicles of god and goddess (Hindu religious). Journal Myanmar Academy Arts Science, XVI. (7), 175-187.

[4] Banarjee, S.C. (1980). Floral and fauna in Sanskrit literature. Naya Prakash, Calcutta.

[5] Beuchert, M. (2004). Symbolik der Pflanzen. Frankfurt, Leipzig: Insel- Taschenbuch.

[6] Brighenti, F. (2001). Shakti cult in Orissa. New Delhi.

[7] Byrne, C. (2007). The one and many gods of Hinduism.Crossroads, 1(2),15-27.

[8] Gan, P.K. (2004). The lion: Mount of goddess Durga. Odisha Review, LXI (3), 22-24.

[9] Grieve, G. (2003). Symbol, idol and murti: Hindu god-images and the politics of mediation. Culture, Theory and Critique, 44, 57-72.

[10] Khamitkar, P.E. (2016). Study on the Prabhavalaya: Aureole of gods and goddesses. Chitrolekha International Magazine on Art and Design, 6(2), 35-52.

[11] Khin, H.M. (2020). A study of Hindu concepts about gods and goddess. Dagon University Research Journal, 11, 58-64.

[12] Phyu, U. (2004). Depiction of nature in the sculptural art of early Deccan (up to 10th century $A D)$. Ph. D. thesis, University of Hyderabad, 123-184.

[13] Sinha, P.N. (1950). A study of the Bhagabata Purana. Theosophical Publishing House, Adyar.

[14] Srivastava, S.K., \& Barmola, K.C. (2013). Rituals in Hinduism as related to spirituality. Indian Journal of Positive Psychology, 4(1), 87-95.

[15] Wilson, H.H. (1961). Vishnu Purana (translated). Punthi Pustak, Calcutta. 